\title{
衝突回避支援装置の効果分析手法
}

\author{
鈴木 桂輔*1，望月 誠 ${ }^{* 2}$ ，見市 善紀 ${ }^{* 3}$ ，山田 喜一 ${ }^{* 4}$
}

\section{Methodologies for evaluating the effectiveness of collision avoidance assistance system}

\author{
Keisuke SUZUKI ${ }^{* 1}$, Makoto MOCHIZUKI*2, Yoshiki MIICHI ${ }^{* 3}$ and Kiichi YAMADA ${ }^{* 4}$ \\ ${ }^{* 1,{ }^{* 2}}$ Kagawa University \\ 2217-20 Hayashi-cho, Takamatsu-shi, Kagawa 761-0396, Japan \\ ${ }^{* 3}$ Toyota Motor Corporation \\ 1 Toyota-cho, Toyota-shi, Aichi 471-8571, Japan \\ ${ }^{*}$ Daido University \\ 10-3 Takiharu-cho, Minami-ku, Nagoya-shi, Aichi 457-8530, Japan
}

\section{Received 17 October 2015}

\begin{abstract}
In this study, methodologies for estimating the accident mitigation ratio using the collision avoidance device are discussed. In these methodologies, the driver's braking or steering and viewing behavior are investigated in a driving simulator. Braking or steering behaviour was identified in terms of the reaction time for braking or steering in order to avoid a collision or lane deviation and viewing behaviour was identified in terms of the duration from looking off a leading vehicle to looking back. Next, to investigate the combined effect based on the reliability of driver and the reliability of system, two different kinds of reliability-estimation model simulating its operating status were constructed. As an example study applying these methods, the effectiveness of the device supplying the aroma to increase the attention level for collision avoidance is quantitatively estimated through the statistical calculations based on the reliability-estimation model.
\end{abstract}

Key words : Driving support, Collision mitigation, Total error of human-machine system, Monte-Carlo simulations, System reliability engineering

\section{1. 緒言}

運転支援装置を市場に投入する際の運転負荷軽減の程度や事故回避支援の程度を定量的に推定し，運転支援装 置の市場投入の優先順位を策定するための知見に資する報告がある.例えば, 事故回避支援システムの開発費と, 軽減される事故被害の程度から推定した損額保険費用の削減額とのバランスから，費用便益を試算（望月他， 2013a）した報告がある.この事故回避支援の程度を推定する手法について考えた場合，衝突回避支援装置を例に とると，その手法は，以下の 3 種類に大別できる.

(1)ドライブレコーダを用いた実環境でのドライバ行動データの取得による運転支援装置の効果分析（Field Operation Test, FOT)

(2)ドライビングシミュレータを用いた運転支援装置の効果分析

(3)ドライバ行動を模擬するシミュレーションによる運転支援装置の効果分析

(1)について，例えば，(中村他，2014）の報告では，実環境にインフラ協調型の右折衝突防止支援システムを構 築し，100 名規模の一般人を対象とした公道での実証実験により，システムによる支援がある場合とない場合で の運転行動を 6 力月間にわたり計測し，この実験で取得した約 1 万件の右折行動データから，システムの事故低

\footnotetext{
No.15-00565 [DOI:10.1299/transjsme.15-00565], J-STAGE Advance Publication date : 12 February, 2016

*1 正員, 香川大学（干761-0396 香川県高松市林町 2217-20）

*2 香川大学

*3 トヨタ自動車 (

*4 大同大学 (T457-8530 愛知県名古屋市南区滝春町 10-3)

E-mail of corresponding author: ksuzuki@eng.kagawa-u.ac.jp
} 
減効果を定量化している. (2)については，これまで多くの報告があるが，一例として，ドライビングシミュレー タを用いて，警報と緩制動を組み合わせた前方衝突防止支援システムを例に，70 名以上の被験者の参加により， システム使用による事故低減効果を分析している報告（本間他，2014）がある. 事故低減効果を高い精度で推定 するためには，この報告に示すように，多くの被験者を募る必要がある. (3)についても多くの報告がるが，例え ば，交通事故のミクロデータを基に選定したヒヤリハット状況を，交通流の中で発生する時系列のシミュレーシ ヨンを提案し, 衝突防止支援システムの実用化による事故低減効果を推定している報告がある（安田他，2012）。 個々の車両挙動の再現には，独自に提案する交通場面に応じて知覚から操作までを模擬できるドライバモデルを 用いている.

これらの事故低減効果の推定手法の特徵を，コストと事故低減効果を推定した結果の精度との関係を観点に概 説すると, 図 1 のようになる. (1)の実環境での調査が, 推定結果の精度の観点で優位であろうが, 同時に, 分析 に要するコストも高い. また, (3)については, 分析に要するコストは低いが, 推定結果の精度の観点で課題が残 る. システム使用時のドライバの運転行動の変容を分析せず，シミュレーションに用いるドライバモデルを構築 した場合, 得られる結果の信頼性が十分でないためである. 筆者らは, (2)のドライビングシミュレータを用いた 手法でドライバの運転行動の特徽を説明しうる状態量をデータベース化したうえで, ドライバの行動を模擬でき るドライバモデルを構築し，シミュレーションによって試行回数の少なさに起因する統計的なエラーを低減し， 推定精度を向上させる手法を提案している. 試行回数と統計的な精度との関係は, 以下の $3 \cdot 2$ において考察す る.

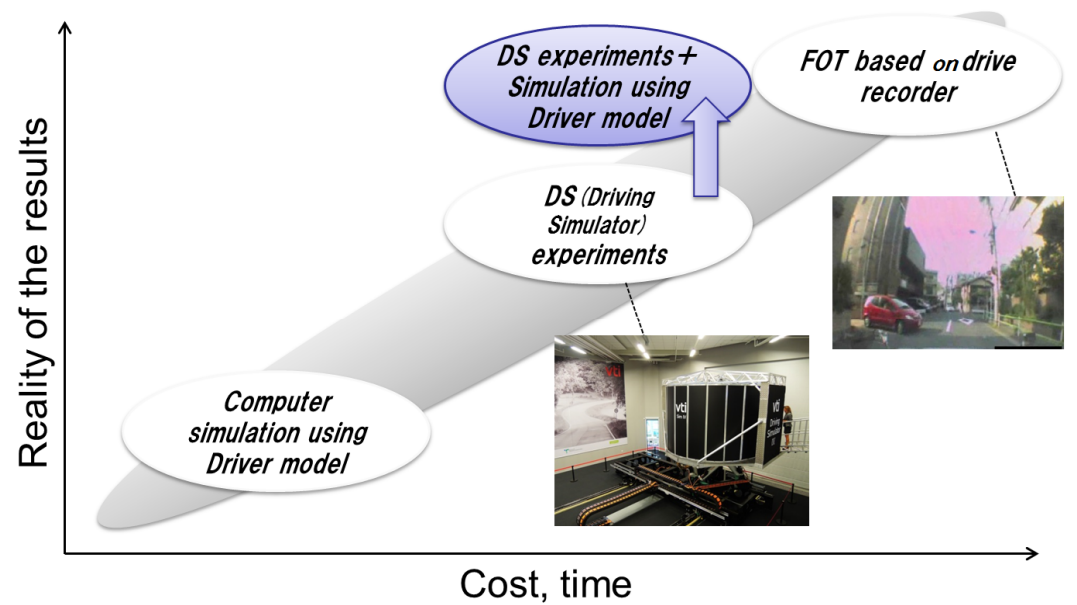

Fig.1 Relation between the cost and the reality of the estimated results in terms of collision mitigation ratio among three major methods to evaluate the effectiveness of the driving support systems. It is important to consider the relation between the cost for the evaluation and the reality of the estimated results simultaneously, when evaluating the effectiveness of the driving support systems in terms of its collision mitigation ratio.

筆者らは，衝突回避支援制動装置や出会い頭衝突回避支援警報装置，右折衝突防止支援警報装置などの事故回 避支援装置を使用した場合におけるシステムとドライバの総合的なエラー発生確率を定量化することによってシ ステムによる事故低減効果を推定する手法を提案している（鈴木他，2012, 2014）(望月他，2013b)。これらの手 法では，ドライビングシミュレータを用いた実験により，ドライバの衝突回避支援行動を特徴づける状態量を分 析したデータベースを用いて，以下の手法を用いて事故回避支援の程度を定量化している．本稿では，これらの 事故回避支援システムを使用した際の事故低減効果を推定する手法を総括し, 留意すべき項目を整理する.

1)ヒューマン・マシン系としての信頼性を表現できるドライバモデルを用いたシミュレーションにより, 事故回 避支援行動を再現する（時系列信頼性モデル）.

2)システム信頼性工学における多自由度系の瞬間故障率を自動車運転環境に適用して, リスクの継続時間で積分 する (状態遷移確率モデル). 


\section{2. 定量化手法}

\section{$2 \cdot 1 \quad$ 統合エラーモデル}

システム使用時における事故低減効果の定量化には，システムが正常に作動する場合のほか，確率的には低い であろうが，システムが何らかの原因で正常に作動しない場合も考慮すべきであると筆者らは考える．ヒューマ ン・マシン系として事故低減効果を推定する場合，例えば，システムの長期使用における過程で，システムへの 過信に基づく依存やシステムの不作動・誤作動により制動や操舵行動に変化が生じること（安部他，2009）が懸 念される. システムを使用するドライバの信頼性に変動が生じるためである.これまでの筆者らの先行研究にお いて, 図 2 に示すように, これら信頼性の変動を考慮したドライバ・システム統合エラーモデルの概念を提案し ている（鈴木，山田，2011）。縦軸はシステムエラー確率，横軸はドライバエラー確率を示し，これらを掛け合わ せた面積が, 統合的なエラー確率を意味する. つまり, 式 (1) に示すように, 図 2 の褐色部分の面積として表現 できるシステム使用時の統合エラーがシステムを使用しない場合のドライバエラー $(\mathrm{Ed} 0 \times 1)$ よりも小さければ, 事故低減に効果的であると判断できる.

Es $\times$ Ed1 $+(1-E s) \times E d 2<$ Ed0

Ed0:システムを使用しない場合のドライバエラー確率

Ed1:システム故障時のドライバエラー確率

Ed2:システム正常作動時のドライバエラー確率

Es:システムの故障確率

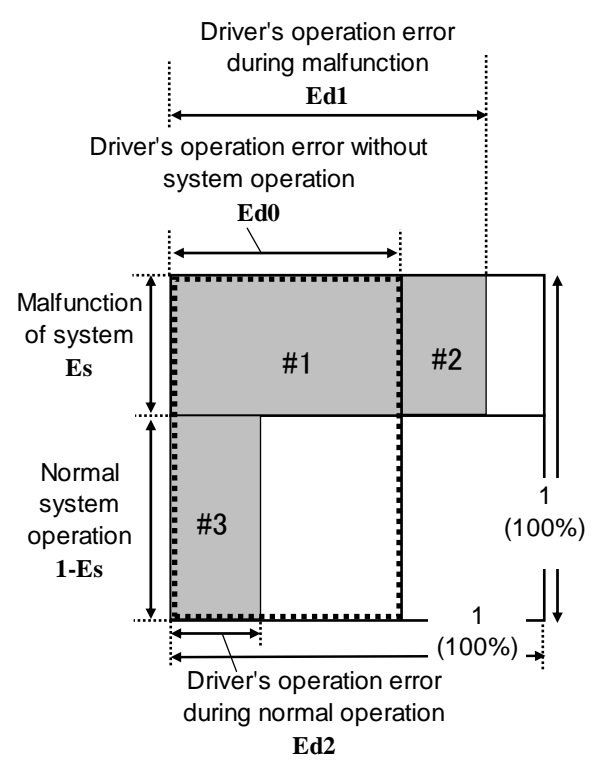

Fig.2 Integrated error of human-machine system. The integrated error as human-machine system can be calculated by multiplying driver error when using the system with system error. The integrated error is depicted as shown with gray area (\#1+\#2+\#3). If the gray area meaning the risk in using the system is smaller than the risk without system (Ed0), it is regarded as the system is effective for reducing the risk of traffic accident.

\section{$2 \cdot 2$ モンテカルロシミュレーションによる定量化（時系列信頼性モデル）}

上記の図 2 の褐色部分の面積（Es $\times \mathrm{Ed} 1+(1-\mathrm{Es}) \times \mathrm{Ed} 2)$ を定量化するために，ドライバとシステムとのヒュー マン・マシン系全体でのエラーの発生状況を時間軸でシミュレーションできるモデルを構築した. ここでは, 認 知過程のドライバ行動（視覚的なディストラクション，わき見を想定）を再現し，エラー継続時間およびエラー 発生間隔を主たる状態量とする信頼性工学の分野でのエラー解析手法に基づくモデルを構築した．以下，このモ 
デルを時系列信頼性モデルと称し，そのモデルの概略を模式的に図 3 に示す.システム側のセンシング・判断・ 支援とドライバ側の認知・判断・操作のそれぞれの過程での作動状況（正常/故障）を再現するモデルである．な お，このモデルでは，システム使用時の統合エラーを定量化するためのシステムエラー確率の設定において，そ の時間間隔と継続時間を図 3 に示すように, システムの作動パターンとして設定する必要がある. このモデルで は，ドライビングシミュレータ実験で得られた，個々のドライバの操作行動に関するデータを用いて，モンテカ ルロシミュレーションにより事故低減効果を定量化する。なお，任意に設定するシステムエラーの時間間隔と継 続時間の設定には，その設定根拠を明確にする必要がある.

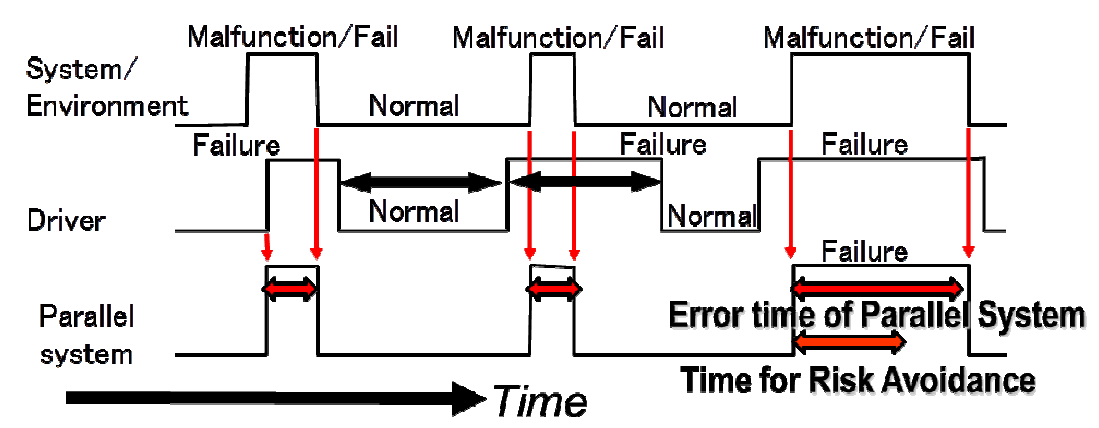

Fig.3 Concept of time series reliability model. The total reliability when using the system can be calculated in time series Monte Carlo simulation. The situation of driver error means the situation when the driver is distracted likelihood of looking aside. The situation of system error means the situation when the system has malfunction. The integrated error as the parallel system can be simulated with time series simulation. When the total error time of the parallel system is longer than the time for risk avoidance, it is determined as the traffic accidents had occurred. This time for risk avoidance can be calculated with Stopping Distance Algorithm. The input values for the simulation such as the error continuation time and error interval time of driver is put into the simulation using the database of driver behavior which is investigated in a driving simulator study.

この時系列信頼性モデルでは，例えば追突回避の場合であれば，ドライバとシステムとが共にエラーとなり， そのエラー（図 3 右下に表記する Error time of Parallel System）が，事故回避余裕時間（Time for Risk Avoidance） よりも長い場合に，事故が発生するという定義で，事故発生の頻度および事故が発生した場合の衝突速度を定量 化している，例えば，前後方向のリスクである先行車両との衝突を回避する場合は，Stopping Distance Algorithm （ISO/DIS15623, 1999）に基づいて，この事故回避余裕時間に相当する衝突回避余裕時間を式（2）のように示す ことができる，このモデルでは，時系列のシミュレーションにおいて発生するリスクイベントの頻度に対する事 故発生の頻度の割合が, 図 1 の褐色部分の面積の合計值を意味する.

$$
T_{c a}=\frac{1}{2} V_{2}\left(\frac{1}{a_{1}}-\frac{1}{a_{2}}\right)+\frac{y}{V_{2}}
$$

Tca :Time for Collision Avoidance [s]

$V_{2}$ : The velocity of following vehicle $[\mathrm{m} / \mathrm{s}]$

$\alpha_{1}$ : The average deceleration of leading vehicle $\left[\mathrm{m} / \mathrm{s}^{2}\right]$

$\alpha_{2}$ : The average deceleration of following vehicle $\left[\mathrm{m} / \mathrm{s}^{2}\right]$

$y$ : The distance between two vehicles [m]

\section{$2 \cdot 3$ 信頼性工学に基づく事故発生確率の定量化（状態遷移確率モデル）}

前述のモンテカルロシミュレーションによる定量化手法では，事故発生確率の定量化のためのモデル化を必要 とするため, 単純な確率計算で事故発生確率を推定することはできない. このため, システム信頼性工学分野の 多自由度系の故障発生確率の概念を用いてシンプルな演算式で推定する手法を筆者らは提案し, 状態遷移確率モ 
デルと名付けた。ドライバの運転パフォーマンスと交通環境の負荷の変動をタイミングダイアグラムで表したも のを図 4 に示す。図に示すように，運転パフォーマンスが低下した状態において，危険事象が発生したにもかか わらず，運転パフォーマンスが回復しない時に衝突回避失敗となり衝突事故が発生する. 記号の定義は下記のと おりである。

$\mu_{11} \quad:$ 運転パフォーマンス低下状態確率 [1/s]

$1 / \mu_{11}:$ 運転パフォーマンス低下状態の継続時間 [s]

$1 / \lambda_{1}$ : 運転パフォーマンスが低下していない継続時間 [s]

$1 / \mu_{11}{ }^{*}$ : 気付き時間 [s]

$t_{0}:$ 衝突発生開始遅れ時間 $[\mathrm{s}]$

$\mu_{2}$ : 衝突率 $[1 / \mathrm{s}]$

$Q_{f} \quad$ : ドライバ意識低下確率

$$
Q_{f}=\frac{1 / \mu_{11}}{1 / \mu_{11}+1 / \lambda_{1}}
$$

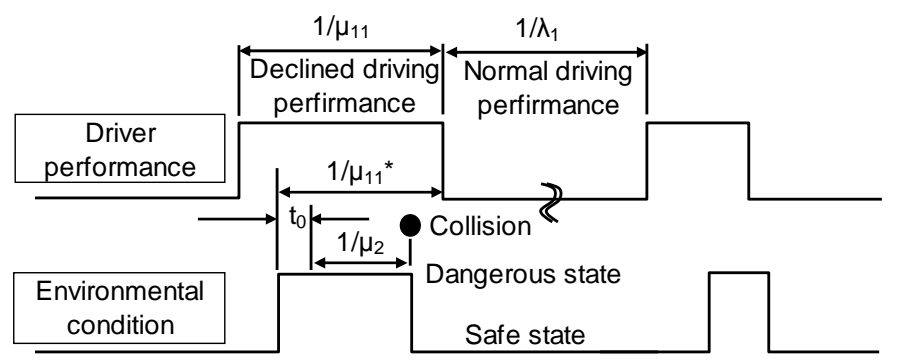

Fig.4 Concept of the state transition probabilistic model. This model is based on the human-machine reliability model which consists of both driver reliability level and environment reliability level. When the reaction time of driver depicted with $\left(1 / \mu 11^{*}\right)$ is longer than $($ to $+1 / \mu 2)$ meaning the time latency after the risk of accidents occurred, the accident occurs. The statistical probability of the accidents can be calculated based on the system reliability of the parallel system. The parallel probability of driver error and environmental error is performed the integration in the duration of the risk continuation, and the accident probability is quantified.

多自由度系システムの信頼性の定量化手法に基づくと, 危険事象があるときの運転パフォーマンス低下回復率 は，以下の式（3）で示すことができる.

$$
e^{-\mu_{11}^{*} t}
$$

$t_{0}$ 秒後から事故が発生する確率は，以下の式（4）で示すことができる.

$$
e^{-\mu_{2}\left(t-t_{0}\right)}
$$

運転パフォーマンス低下時の衝突率は $\mu_{2}$ であるので， $t_{0}$ 秒後から衝突が発生する確率 $P_{1}$ は，以下の式（5）の ように記述することができる. 式（5）を展開すると，最終的に式（6）を得る.

$$
\begin{aligned}
p_{1} & =\int_{t_{0}}^{\infty} e^{-\mu_{11}{ }^{*}} e^{-\mu_{2}\left(t-t_{0}\right)} \mu_{2} d t \\
& =\frac{\mu_{2}}{\mu_{11}{ }^{*}+\mu_{2}} e^{-\mu_{11}{ }^{*} t_{0}}
\end{aligned}
$$

なお，このモデルを扱う上で留意すべき点は，式（6）はシステムの信頼度を表現する項を含んでいないため，

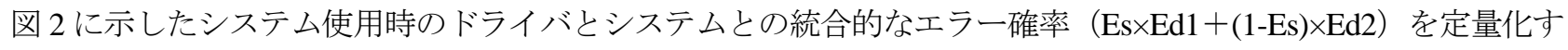
る際は，以下の 1)-3)の作業が必要となる.

1） システムが正常に作動する場合のドライバ行動データに基づいて， $P_{1} \quad(\mathrm{Ed} 2$ に等しい）を式（6）を用いて 算出 
2）システムが不作動誤作動を発生する場合のドライバ行動データに基づいて， $P_{1}$ （Ed1 に等しい）を式（6）を 用いて算出

3) リスクイベントの発生頻度の総数に対して, システムが正常に作動しない(不作動誤作動)システム故障確率 Es の定量值を設定し，上記の Ed1 と Ed2 とともに式（1）に代入し，システム使用時の統合的なエラー確率 を定量化

\section{$2 \cdot 4$ 事故発生確率定量化手法の比較}

時系列信頼性モデルと状態遷移確率モデルの特徵について総括する. 目的に応じて，二種のモデルを使い分け る必要がある.

1）時系列信頼性モデル

・交通環境を示寸パラメータ及び，ドライバの運転パフォーマンスを示すパラメータの変動をドライバモデル に反映する事が可能であり，多様なシーンへの適用が可能

・評価対象となるシーンごとに，ドライバの認知行動や回避行動をモデル化したシミュレーションモデルの構 築が必要

・制御介入型のシステムによる事故回避支援機能 (時系列減速度プロファイルなど) の詳細を再現できるため, 制御仕様別でのドライバ行動の変化を考慮した，システムの事故低減効果を推定可能

2）状態遷移確率モデル

・信頼性工学における信頼度関数に基づいて衝突率を算出するため, ドライバモデルの構築を行わずに，単純 な確率計算によりその衝突率を分析可能

・情報提示型システムを使用した際のシステムごとのドライバ行動の変化は考慮できるものの, 制御介入型の システムによる事故回避支援機能（時系列の減速度プロファイルなど）の詳細を再現できないため，これら を必要としない情報提示型のシステムの評価に適用が可能

\section{3. 留意すべき課題}

\section{$3 \cdot 1$ 代表的シナリオの設定}

ドライビングシミュレータを用いた実験でのシナリオの設定にあたっては，実験で得られた結果が，実際の道 路交通環境でのドライバの制動操作行動を代表している必要がある. そこで，例えば交通事故の実態を分析した マクロデータ（ITARDA, 2009）およびイベントデータレコーダを用いた報告書（阿賀他，2010）に基づいて，例 えば，追突事故の場合であれば，追突発生時の先行車両との車間時間および走行速度を決定し，ドライビングシ ミュレータ実験のシナリオを設定するという手法をとっている．多様にあるシナリオを全て考慮することは現実 的でないため, 代表的なシナリオの設定が必要である. 追突事故を再現するシナリオを, 以下の図 5 に例示寸る.

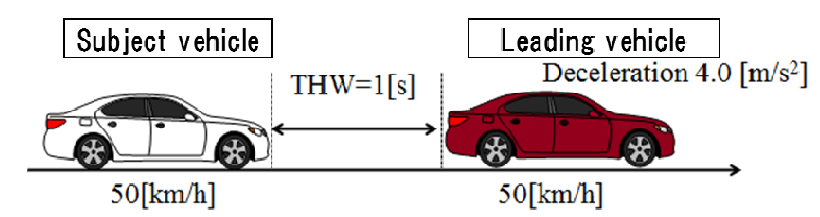

Fig.5 Scenario for simulating the typical rear-end collision. The scenario of risk event is determined based on the database of traffic accidents. In case of the rear-end collision, the typical accident meaning the most frequent accident is happened when the velocity of a leading vehicle and following vehicle is $50 \mathrm{~km} / \mathrm{h}$ and the time head way is 1 second as depicted in the figure.

\section{$3 \cdot 2$ ドライバエラーの定量值に求められる精度}

事故発生確率を精度良く分析するためには, 確率的誤差, 例えば, 統計的な $95 \%$ 信頼区間（confidence interval） を，可能な限り小さくすることが必要である. 実験回数と 95\%信頼区間との関係を以下の図 6 に示す.この図で は，確率的に 5\%の割合で事故が発生する場合から 50\%の割合で事故が発生する場合について，95\%信頼区間を 
示している. 5\%の割合で衝突が発生するようなシナリオにおいて，95\%信頼区間を，例えば，その $1 / 2$ の $2.5 \%$ とするためには, 矢印部分に示すように, 同一条件において 300 回程度の実験回数が必要である. しかしながら, 同一の実験参加者が複数回のヒヤリハット状態（衝突シナリオ）を短時間で体験すると，実際の走行環境と異な った条件での計測結果となることが懸念される．実験条件別でのヒヤリハットの頻度を実験参加者あたり 5 回程 度の設定とするのが妥当と考えると, 例えば 300 回の実験回数を実現するためには, 60 人の実験参加者を確保す る必要があり, 現実的ではない. ドライビングシミュレータ実験のほかに，ドライバモデルを用いたシミュレー ションや, システム信頼性工学分野の, 多自由度系の故障発生確率密度関数による演算など組み合わせ, 危険回 避能力の分析について, 走行回数を増やして 95\%信頼区間が小さい状態での事故低減効果の分析が必要となる. 同時に，ドライビングシミュレータなどを用いた実験解析での事故の発生確率を，できるだけ高く設定すべきこ とが分かる. 事故の発生確率が高いほど 95\%信頼区間も増加する傾向にあるが, 事故の発生確率に対する 95\%信 頼区間の相対的な割合は減少する傾向にあるためである.

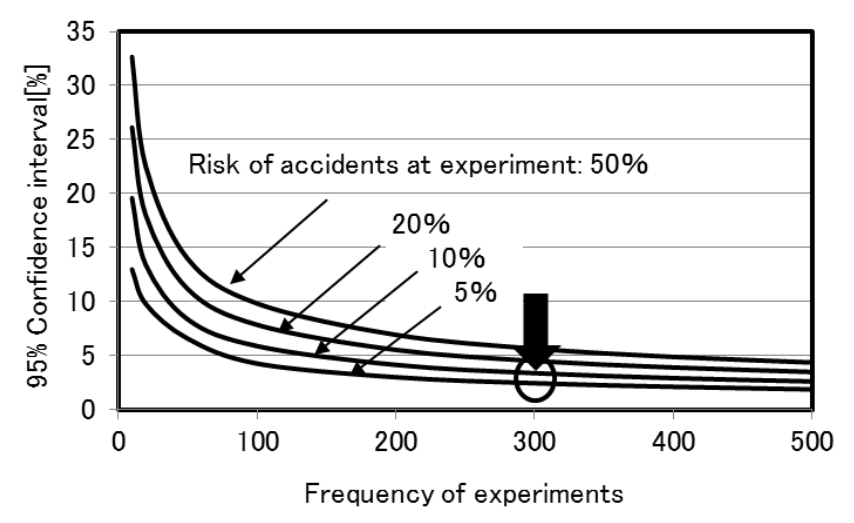

Fig.6 Relation between frequency of experiments (frequency of accident avoidance) and confidence interval. It is important to increase the frequency of risk avoidance trials in simulation and also to increase the risk of collisions in driving simulator studies simultaneously to minimize the $95 \%$ confidence interval meaning the error of the estimated collision mitigation ratio.

\section{$3 \cdot 3$ 実験において衝突確率を高く設定する意味}

実際の道路交通環境では，例えば，事故発生確率が高い交通環境においても，10 $0^{-5}$ 程度以下の頻度である。し かしながら，ドライビングシミュレータ実験では，これと比較して極めて高い $0.1 \times 10^{-1} \sim 0.5 \times 10^{-1}$ 程度の確率で事 故が発生するシナリオを設定している. 図6に示したように，事故発生確率を高くしたヒヤリハット状態では信 頼区間が小さく, 確率的誤差を小さく維持できるためである.このため, 実際の交通環境での事故発生確率に換 算するためには，このような実験で設定するようなヒヤリハットが実際の道路交通環境で発生する確率を掛け合 わせる必要がる．なお，システムの仕様別での事故回避支援システムの事故低減効果を見積もることのみが目的 であれば，ヒヤリハットが発生する確率を掛け合わせる必要がなく，実験で設定したヒヤリハット条件における 制御仕様別での事故発生頻度を比較すればよい.

\section{4. 追突発生確率低減効果の分析例}

事故低減効果の分析例として, 状態遷移確率モデルを例に, 先行車両が急減速を行う条件下での追突発生確率 の定量化および運転中のドライバへの芳香の供給による事故低減効果の推定例を示す. なお，前述の図 2 に示し たように, システムが不作動となる状況も考慮して, 事故発生確率の低減効果を推定する必要があるが, 今回は, まず，システムが正常に作動する場合の事故発生確率の低減効果の定量化手法を例示する. 実験参加者は, 若年 男性 22 名（平均年齢 $23.5 \pm 0.96$ 歳）とした。倫理委員会での審議を経た後で実験を実施した。なお，実験の開始 前には, ドライビングシミュレータの運転に習熟するための練習走行を 20 分間設定したうえで, 被験者を 11 名 ずつの 2 群に分け, 芳香を供給する条件を前半に体験するドライバ群と, 芳香を供給しない条件を前半に体験す るドライバ群を設定することにより，実験プロトコルの順序効果を低減するように配慮した． 
図 7 に，先行車両に追従中に，先行車両が急減速を開始した直後の制動反応時間の累積頻度を示す。運転中に 芳香（リモネン）を，バブリングによりカニューラで，ドライバに供給した場合（四角形）と供給しない場合（濃 菱形）の結果を示す．芳香の供給は，運転中の覚醒レベルを維持し，危険状態を認知する時間の遅延を抑制する 目的で行った。ここで，システム信頼性工学では，63\%ile 值を代表值として扱うことから，式（1）の 1/ $\mu_{11} *$ は, 通常は $1.67 \mathrm{~s}$ となり，芳香を供給した場合は $1.47 \mathrm{~s}$ である。これは，63\%のドライバは，芳香を供給しない場合で は 1.67 秒以内に制動操作を開始していることを意味しており, 芳香の供給により $0.2 \mathrm{~s}$ 制動操作が短縮したことを 意味している.

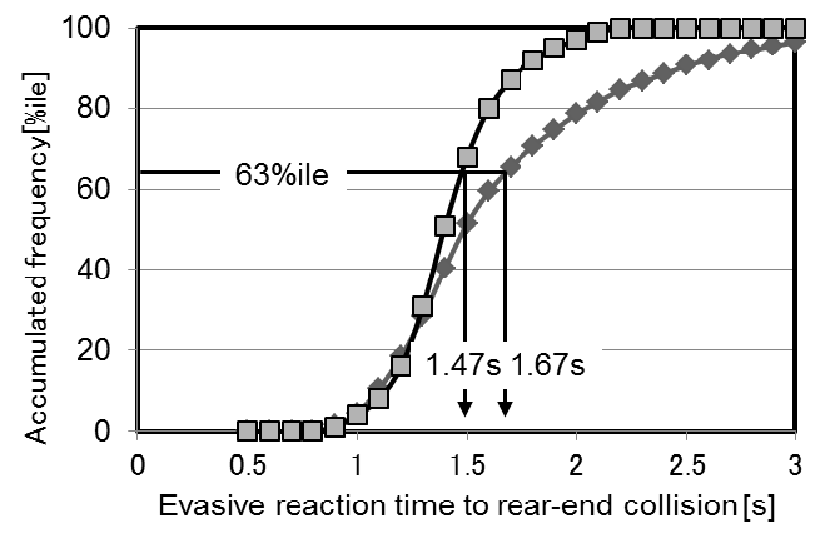

Fig.7 Evasive braking reaction time $\left(1 / \mu_{11} *\right)$ for state transition probabilistic model. For the estimation of the effectiveness of the systems in terms of the collision mitigation ratio using the state transition probabilistic model that the authors have proposed, we focus on the reaction time to avoid the risky driving situation in terms of its $63 \%$ of accumulated frequency. In this study, it is shown that the reaction time to avoid the collision to the leading vehicle is shortened when the aroma was supplied to the driver.

表 1 には，芳香を供給しない場合と芳香を供給した場合での，追突を回避する際のドライバ行動の特徵量を示 している.

Table 1 Parameters for rear-end collisions

\begin{tabular}{c|c|c|l}
\hline \hline Parameter & $\begin{array}{c}\text { Value\#1 } \\
\text { (Without Aroma) }\end{array}$ & $\begin{array}{c}\text { Value\#2 } \\
\text { (With Aroma) }\end{array}$ & \multicolumn{1}{|c}{ Definition } \\
\hline $1 / \lambda_{1}$ & $1[\mathrm{~h}]$ & $1[\mathrm{~h}]$ & $63 \%$ of the drivers may have one distraction per hour \\
\hline $1 / \mu_{11}$ & $1.90[\mathrm{~s}]$ & $1.90[\mathrm{~s}]$ & Time for declined driving performance \\
\hline $\mathrm{Q}_{\mathrm{f}}$ & $5.28 \times 10^{-4}$ & $5.28 \times 10^{-4}$ & See Fig.4 \\
\hline $1 / \mu_{11}^{*}$ & $1.67[\mathrm{~s}]$ & $1.47[\mathrm{~s}]$ & $63 \%$ ile of braking reaction time \\
\hline$\omega_{\mathrm{f} 0}$ & $1[/ \mathrm{h}]$ & $1[/ \mathrm{h}]$ & Risky situations occur once per hour \\
\hline $\mathrm{t}_{0}$ & $3.00[\mathrm{~s}]$ & $3.00[\mathrm{~s}]$ & Time margin before entering a collision area \\
\hline $1 / \mu_{2}$ & $0.450[\mathrm{~s}]$ & $0.450[\mathrm{~s}]$ & Average time to a collision after entering a collision area \\
\hline
\end{tabular}

(1) ドライバが注意散漫状態で，ヒヤリハット状況に遭遇する時間的確率

$$
Q_{f} \omega_{f 0}=5.28 \times 10^{-4}
$$

これは, 1,900 時間の走行において一度の確率で, 追突が発生する可能性のある危険な状況を体験していること を意味している. 
（2）追突が発生する可能性のあるヒヤリハット状況での追突発生確率

$$
\begin{gathered}
p_{1}=\frac{\mu_{2}}{\mu^{*}+\mu{ }_{2}} e^{-\mu_{11}^{*} t_{0}} \\
=\frac{1}{1+\frac{0.450}{1.67}} e^{-\frac{1}{1.67} \times 3.0}=1.31 \times 10^{-1}
\end{gathered}
$$

(3) ドライバが注意散漫な状況で，追突が発生する確率

$$
\omega_{f}=Q_{f} \omega_{f 0} \frac{\mu_{2}}{\mu_{11}^{*}+\mu_{2}} e^{-\mu_{11}^{*} t_{0}}=6.90 \times 10^{-5}
$$

これは，ドライバの年間の走行時間を 500 時間とすると，30 年に一回の確率で，追突を引き起こすことを意味 している.

また，芳香を供給した場合の事故低減効果を定量的に把握するために，追突が発生する可能性のあるヒヤリ八 ット状況での追突発生確率を推定寸ると，以下となる.

$$
\begin{aligned}
p_{1} & =\frac{\mu_{2}}{\mu_{11}^{*}+\mu_{2}} e^{-\mu_{11}^{*} t_{0}} \\
& =\frac{1}{1+\frac{0.450}{1.47}} e^{-\frac{1}{1.47} \times 3.0}=9.95 \times 10^{-2}
\end{aligned}
$$

前述の $P_{I}$ の值を基に判断すると，事故発生確率は，芳香の供給により $24 \%$ 低減することが分かる.

\section{5. 総 括}

事故低減効果を推定するためには，その確率的誤差を小さくする必要がある．筆者らは，ドライビングシミュ レータを用いてドライバの危険回避行動を特徴づける運転行動をデータベース化し，このデータベースを用いた シミュレーション，もしくはシステム信頼性工学の分野の多自由度系の故障率の概念を用いて, 確率的誤差を小 さくしたうえで，システムの制御パターン別での事故発生頻度を推定する手法を提案した．本稿では，それらの 解析手法を例示したうえで，その一つの手法である状態遷移確率モデルを用いて，芳香供給による追突事故の低 減効果の推定手法を例示した.

また，本稿で議論するようなシステムの事故低減効果について，推定結果の信頼性を向上させるために留意す べき課題について，実環境での代表的事故シナリオの選定方法を例に概説した．また，統計的な観点で，得られ る推定值の信頼性を高めるために必要な, シミュレーションにおけるリスクイベントの設定回数のほか, ドライ ビングシミュレータ実験でのシナリオで設定すべき事故の発生確率について, 推定結果の 95\%信頼区間を基に, 議論した.

本稿では，筆者らが提案する，事故回避支援を目的とした運転支援装置の事故低減効果の推定手法の一例を示 した．今後の課題として，代表的な被験者ドライバの定義を明確にし，例えば，DSQ（石橋他，2004）などを用 いたドライバの運転特性をベースとした, 被験者層の選定手法について議論すべきである.

\section{文献}

安部原也，伊藤誠，山村智弘，追突警報タイミングの違いによる正警報および久報に対する減速行動への影響に 関する考察, ヒューマンインタフェース学会論文誌, Vol. 11, No.3 (2009), pp.265-277.

阿賀正己，田中信，青木宏文，里美洋平，被害軽減ブレーキシステムの効果予測手法の開発（第 2 報）, 自動車技 術会学術講演会前刷集, No.68-10 (2010), pp.5-8.

安藤憲一, 田中信壽, 衝突回避・被害軽減ブレーキの性能評価と効果推定に関する検討 (第 4 報), 自動車技術会 
学術講演会前刷集，\#20135870 (2013).

石橋基範, 大桑政幸, 赤松幹之, 運転スタイル・負担感受性の個人特性 指標と運転行動, 自動車技術, Vol. 58, No.12 (2004), pp.34-39.

本間亮平, 菊地一範, 若杉貴志, 宇野章則, 浦井芳洋, 吉田傑, 前方車両衝突防止支援システムの効果予測-警報 緩制動の有効性-，自動車技術会論文集，＃20144296，Vol.45，No.2 (2014)，pp.393-398.

ISO/DIS15623, Performance requirements and tests procedures, Road Vehicles-Forward Vehicle Collision Warning Systems-Performance Requirements and tests Procedures (1999).

Institute for Traffic Accident Research and Data Analysis, Report of Japan Traffic Accidents Databases (2009).

望月誠, 久保谷寛行, 新居良紀, 鈴木桂輔, 出会い頭衝突防止支援システムの事故低減効果の定量化及びシステ ムのエラ一許容量に関する分析手法，自動車技術会論文集，Vol.44，No.2，＃20134230 (2013a), pp.621-626.

望月誠，新居良紀，鈴木桂輔，山田喜一，時系列信頼性モデルを用いた出会い頭事故におけるディストラクショ ン低減効果の評価，計測自動制御学会論文集，Vol.49，No.11 (2013b), pp.1074-1081.

中村俊佑, 菅沼英明, 菊地一範, 本間亮平，インフラ協調型右折衝突防止支援システムの効果評価，自動車技術 会学術講演会前刷集，\#20145328 (2014).

鈴木桂輔，杉本成基，見市善紀，原弘一，複数の事故回避支援装置を搭載した場合のドライバの運転特性，自動 車技術会論文集，Vol.45，No.1(2014)，pp.141-146.

鈴木桂輔，新居良紀，伊藤祥雄，山田喜一，状態遷移確率モデルに基づくドライバのディストラクション低減効 果評価モデルの構築，自動車技術会論文集，Vol.43，No.6 (2012)，pp.1321-1326.

鈴木桂輔, 山田喜一，ドライバとシステムの統合エラーを考慮した事故回避支援システムの有効性に関する基礎 的検討，自動車技術会論文集，Vol.42，No.1 (2011)，pp.95-100.

安田浩志, 小里明男, 田中 新, 持田 勤, 田島 淳, ASSTREET を用いた追突事故における予防安全システム の効果予測手法，自動車技術会論文種集，＃20124272，Vol.43，No.2 (2012)，pp.599-604.

\section{References}

Abe, G., Itoh, M. and Yamamura, T., Effects of different alarm timings for forward collision warning system on driver's response to true and missed alarms, Transactions of Human Interface, Vol.11, No.3 (2009), pp.265-277 (in Japanese).

Aga, M., Tanaka, S., Aoki, H. and Satomi, Y., Development of the Safety Impact Methodology for Effectiveness Estimation of a Pre-Crash Safety System (Second Report), Proceedings of Society of Automobile Engineers of Japan, No.68-10 (2010), pp.5-8 (in Japanese).

Ando, K. and Tanaka, N., An Evaluation Protocol for Collision Avoidance and Mitigation Systems and its Application to Safety Estimation (Fourth Report), Proceedings of Society of Automobile Engineers of Japan, \#20135870 (2013) (in Japanese).

Ishibashi, M., Okuwa, M. and Akamatsu, M., Driver's Characteristics Index of Driving Style/Workload Sensitivity for a Driving Behavior Study, Journal of Society of Automotive Engineers of Japan, Vol.58, No.12 (2004), pp.34-39 (in Japanese).

Homma, R., Kikuchi, K., Wakasugi, T., Uno, A., Urai, Y. and Yoshida, S., Evaluation of Forward Vehicle Collision Mitigation Systems -Effectiveness of Warning Braking-, Transactions of J Society of Automobile Engineers of Japan, \#20144296, Vol.45, No.2 (2014), pp.393-398 (in Japanese).

ISO/DIS15623, Performance requirements and tests procedures, Road Vehicles-Forward Vehicle Collision Warning Systems-Performance Requirements and tests Procedures (1999).

Institute for Traffic Accident Research and Data Analysis, Report of Japan Traffic Accidents Databases (2009) (in Japanese).

Mochizuki, M., Kubotani, H., Nii, Y. and Suzuki, K., Evaluation of the Effectiveness of Collision-prevention Support Information at a Blind Intersection and Analysis Concerning the Acceptable Reliability of the Sensors, Transactions of Society of Automobile Engineers of Japan, Vol.44, No.2, \#20134230 (2013a), pp.621-626 (in Japanese).

Mochizuki, M., Nii, Y., Suzuki, K. and Yamada, K., Evaluation of the Distraction Reduction by Driving Support Systems in a Collision at Intersection Based on the Time Series Reliability Model, Transactions of The Society of Instrument and Control Engineers, Vol.49, No.11 (2013b), pp.1074-1081 (in Japanese).

Nakamura, S., Suganuma, H., Kikuchi, K. and Homma, R., Effect Evaluation of Vehicle-Infrastructure Cooperative Right-Turn Collision Prevention System, Proceedings of Society of Automobile Engineers of Japan, \#20145328 (2014) 
(in Japanese).

Suzuki, K., Sugimoto, N., Miichi, Y. and Hara, K., Driver Behavior When Installing with Two Different Driving Support Functions, Journal of Society of Automobile Engineers of Japan, Vol.45, No.1 (2014), pp.141-146 (in Japanese).

Suzuki, K., Nii, Y., Ito, S. and Yamada, K., Evaluation Model for Quantifying the Reduction of Driver's Mental Distraction Based on the State Transition Probabilistic Model, Transactions of The Society of Instrument and Control Engineers, Vol.43, No.6 (2012), pp.1321-1326 (in Japanese).

Suzuki, K. and Yamada, K., Evaluating the Effectiveness of Driving Support System for Collision Avoidance with a View to the Integrated Error of Driver and System, Transactions of Society of Automobile Engineers of Japan, Vol.42, No.1 (2011), pp.95-100 (in Japanese).

Yasuda, H., Kozato, A., Tanaka, S., Mochida, T. and Tajima, J., Pre-collision System Benefit Estimation Method Based on Rear-end Collisions Generatead by ASSTREET, Transactions of Society of Automobile Engineers of Japan, \#20124272, Vol.43, No.2 (2012), pp.599-604 (in Japanese). 